\title{
Earth fissures in Qinglong Graben in Yuncheng Basin, China
}

\author{
Jianwei Qiao ${ }^{1}$, Jianbing Peng ${ }^{1,2}, *$, Yahong Deng ${ }^{1}$, Yanqiu Leng ${ }^{1}$ \\ and ZhenJiAng MenG ${ }^{1}$ \\ ${ }^{1}$ School of Geological Engineering and Geomatics, Chang'an University, Xi'an 710 054, Shaanxi, China. \\ ${ }^{2}$ Key Laboratory of Western China Mineral Resources and Geological Engineering, Xi'an 710 054, Shaanxi, China. \\ ${ }^{*}$ Corresponding author. e-mail: dicexy_1@126.com
}

MS received 9 March 2016; revised 19 June 2017; accepted 25 June 2017; published online 14 February 2018

Qinglong Graben is located in southeastern Yuncheng Basin, China flanked by two north-east trending normal faults, where the geological condition is favourable for generating earth fissures. Since 1978, five earth fissures have formed in Qinglong Gaben. In the present work, a series of geological investigation consisting of site investigation, geological drilling and trench excavation was used to characterise and determine the reasons for the formation of the earth fissures. The site investigation indicated that the trend of the five earth fissures are parallel to the general strike of the normal fault, i.e., geological drilling and trench studies revealed that syn-sedimentary fault is the key reason for the formation of the earth fissures. Additionally, over-exploitation of groundwater and erosion process are important factors in the development and expansion of the earth fissures in Qinglong Graben. The earth fissures forming process in Qinglong Graben can be divided into three stages: the regional extension first caused normal faults under the surface, and then the pumping action of excessive groundwater induced the normal faults propagate to the surface, and finally the erosion promoted the formation of the current earth fissure.

Keywords. Earth fissure; Qinglong Graben; Yuncheng Basin; syn-sedimentary fault; forming process.

\section{Introduction}

Earth fissures are defined as long, linear tensile structures formed on land surface with or without vertical offsets. They can be several kilometers long and can extend to the depth of aquifers (Carpenter 1993; Ayalew et al. 2004; Martin and Burbey 2010; Budhu 2011). Earth fissures cause environmental problems and bring great damages to farmlands, roads, buildings and other infrastructures, thereby causing major financial losses $(\mathrm{Wu}$ et al. 2004; Pacheco-Martínez et al. 2013; Youssef et al. 2014).
Earth fissures not only cause injuries to humans and livestock, but also damage urban infrastructure, such as traffic facilities, piping, and buildings and indeed cause serious environmental problems (Wu et al. 2004; Budhu 2011). The costs associated with earth fissure are critical in North China. According to Wang et al. (2001), economic losses in North China can be up to 6.4 billion dollars. Earth fissures cannot be traced until the damages have already begun, such as cracks in walls.

Pumping-induced land subsidence and earth fissures have been observed in many places in America, Asia, Africa and Europe and documented 
in the literature (Rudolph et al. 1991; Lee et al. 1996; Allis 2000; Ngecu and Nyambok 2000; Sapigni et al. 2003; Holzer and Galloway 2005). Feth (1951) and Jachens and Holzer (1979) suggested that differential subsidence is the primary mechanism through which earth fissures are formed. Lofgren (1978) and Helm (1994) showed that horizontal seepage stress has a significant role in the origin of earth fissures. Jachens and Holzer (1982) argued that tensile strains caused by bending of the strata above the buried bedrock features in response to the differential compaction are the formation mechanism of earth fissures. Bell (1981) and Sheng et al. (2003) proposed that earth fissures are formed due to tensile stress. Burbey (2002) suggested that horizontal deformation in aquifers contributes to earth fissure development. Budhu (2008) showed that the most efficient mechanism for earth fissure formation is a combination of bending and shearing. Budhu (2011) also reported that simple shear strain and rotation are the indicators for initiation of earth fissures.

In addition to the above-mentioned factors, earth fissures can also occur due to other factors. $\mathrm{Li}$ et al. (2000) suggested that 'soil collapse' play an important role in the formation of earth fissure. Williams et al. (2004) reported that crustal extension is also responsible for formation of earth fissures. Ramelli et al. (2003) and Sarkar (2004) presented that even earthquakes can create earth fissures. Sun et al. (2009) proposed that weak tensile characteristics of loess are important factors in the development of earth fissures in China's loess areas. Especially, the pre-excited faults play important role in the formation of earth fissures (Burbey 2002; Sheng et al. 2003; Peng et al. 2008, 2013).

The first earth fissure in Yuncheng Basin occurred in Banpo village in 1975, and the total length was $1500 \mathrm{~m}$ (Wang 1984). Since then, there were many incidents of earth fissures throughout in Yuncheng Basin (Li et al. 2000; Xu et al. 2010; Liu et al. 2013). Now, earth fissures have become an important geohazard in Yuncheng Basin. Research indicated that heavy rainstorm, groundwater pumping and loess erosion are the main reasons for the formation of earth fissures in Yuncheng Basin (Li et al. 2000; Xu et al. 2010). In the current work, geological drilling and trench excavation were done which revealed that the pre-excited faults are the key factors for the formation of earth fissures.

\section{Geological setting and earth fissures}

\subsection{Gelogical setting}

Yuncheng Basin is located in southern Fenwei Graben System in northern China. It is bounded by Zhongtiao Mountain (ZM) in the south and east, Emei Msa in the north, and Yellow River in the west (figure 1). It formed in Oligocene and the quaternary sedimentary thickness can be up to $700 \mathrm{~m}$ (Zhang 2000). It is a tectonic graben representing a topographic depression that is flanked by two NE trending faults, namely Zhongtiao piedmont margin fault (F1) and the southern Emei Mesa margin fault (F2). F1 is a listric normal fault with a length of $130 \mathrm{~km}$, and the dip is NW with dip angle between $60^{\circ}$ and $80^{\circ}$. Cheng and Yang (2002) divided F1 into three sections, viz., Xiaxian section (northern section), Haizhou section (middle section) and Hanyang section (southern section). Since Holocene, all these three sections have been tectonically active (Tian et al. 2013; Miao et al. 2014; Wang et al. 2015).

Qinglong Graben is located in the northeastern Yuncheng Basin (figure 1). It is controlled by the northern F1 and the eastern MT margin fault (F4) with strike NE (figure 2). The tectonic activity of F4 has been active and the vertical offset is up to $5 \mathrm{~m}$ since the late Pleistocene and $1 \mathrm{~m}$ since Holocene ( $\mathrm{Li}$ et al. 1994). Quaternary strata, from Pleistocene to Q4, are extensively presented as different loess, clays and sandy soils with a degree of consolidation (Wang et al. 2000).

\subsection{Description of earth fissures in Qinglong Graben}

Since 1980s (Wang 1984), five earth fissures have occurred in Qinglong Graben, namely f1, f2, f3, f4 and $f 5$ (figure 2). As showing in figure 2, these five earth fissures line semi-parallel to each other and the flaked normal faults. The strike of these earth fissures ranges from NE $35^{\circ}$ to NE65 ${ }^{\circ}$, almost similar to the trend of Qinglong Graben.

At a distance of $5 \mathrm{~km}$ from the ZM, fissure 1 was located in the eastern Qinglong Graben (figure 2). It appeared in 2000 and affected two villages with a length of about $2.3 \mathrm{~km}$. The vertical offset was up to $25 \mathrm{~cm}$ and the ground dilation was more than several millimeters (figure 3a). The trend of this fissure was in the range of NE $50^{\circ}-$ NE $65^{\circ}$. 


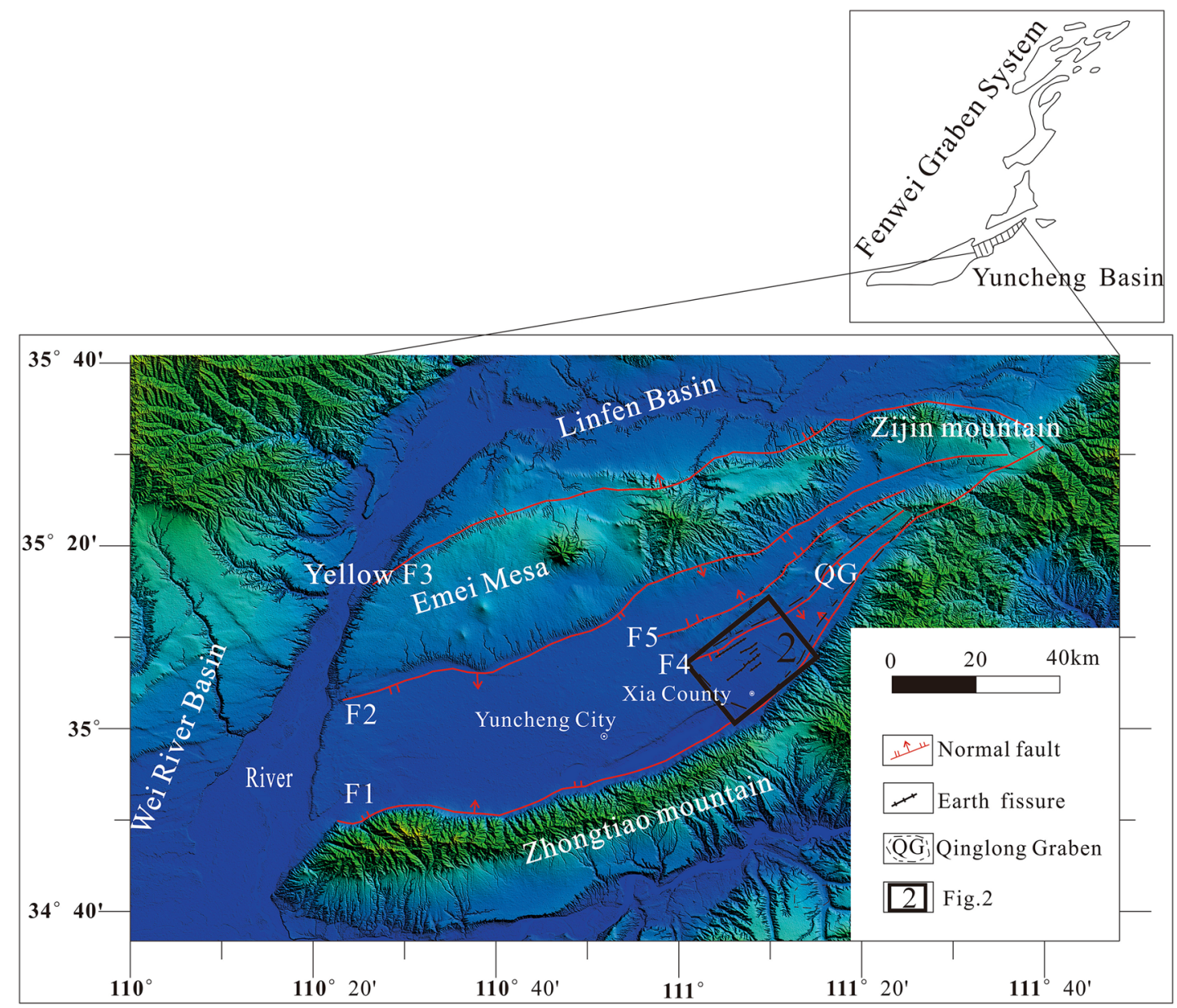

Figure 1. Regional setting of the Yuncheng Basin in Fenwei Graben System and the location of Qinglong River Graben in Yuncheng Basin. Yuncheng Basin and Linfen Basin are demarcated by Emei Mesa, and the Yellow River separate Yuncheng Basin and Wei River Basin. F1: Zhongtiao piedmont margin fault; F2: The southern Emei Mesa margin fault; F3: The northern Emei Mesa margin fault; F4: The eastern Mingtiaogang (MT) margin fault; F5: The western MT margin fault.

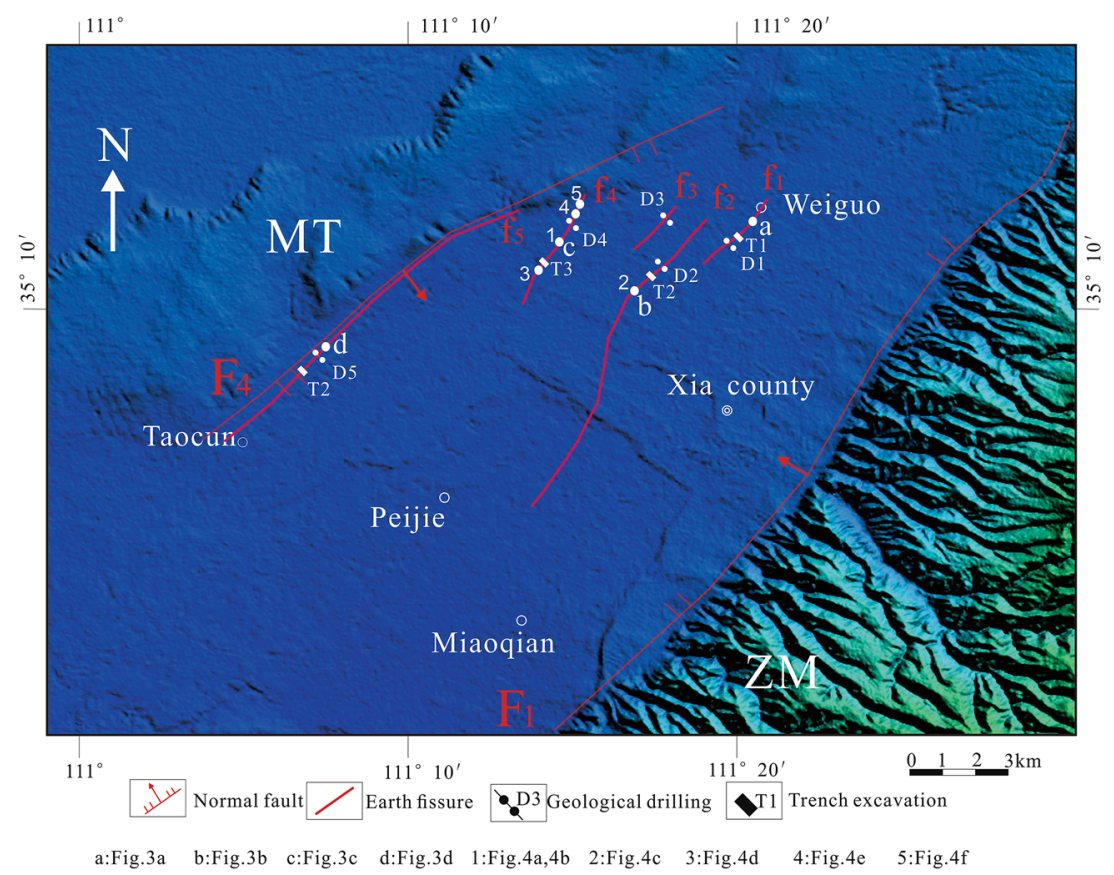

Figure 2. Map showing the flanked normal faults and ground fissures in the current study area. 

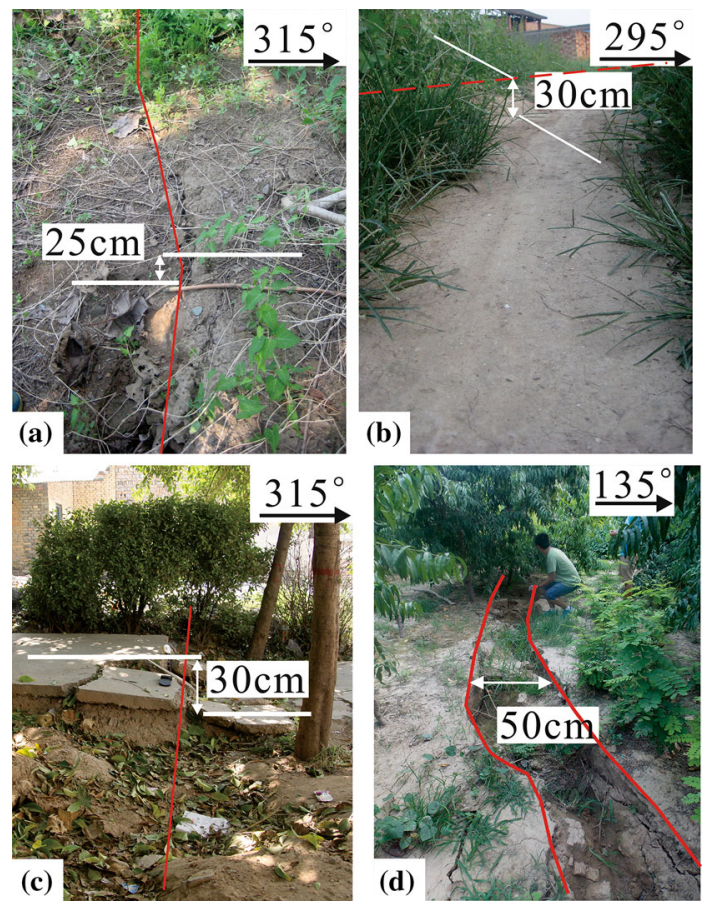

Figure 3. Photos of earth fissures. (a) Fissure 1 showing a vertical offset of $25 \mathrm{~cm}$. (b) Fissure 2 showing a vertical displacement of $30 \mathrm{~cm}$. (c) Fissure 4 showing a vertical offset of $30 \mathrm{~cm}$. (d) Fissure 5 showing a width of $50 \mathrm{~cm}$.

At a distance of $6.2 \mathrm{~km}$ from the $\mathrm{ZM}$, fissure 2 was the second longest earth fissure in Qinglong Graben (figure 2). Its traced length was about $9.5 \mathrm{~km}$, the scarp was $30 \mathrm{~cm}$ (figure $3 \mathrm{~b}$ ) and the horizontal displacement was inconspicuous. It was in July 1995, when this fissure first drew villagers' attention and in June 2013, affected seven villages in total. The trend of this fissure was in the range of $\mathrm{NE} 45^{\circ}-\mathrm{NE} 65^{\circ}$. This earth fissure was first to appear in edge and then extended to the center.

With a length of about $1.4 \mathrm{~km}$, fissure 3 was located at the center of Qinglong Graben (figure 2). It occurred in June 1990. The fact that fissure 3 was relatively short with a little dislocation and appeared only in farmland in the eastern Baizhang village means that it got little attention in the beginning. In fact, no scarps were formed on both sides of this earth fissure. The orientation of this earth fissure was in the range of $\mathrm{NE} 45^{\circ}-\mathrm{NE} 65^{\circ}$.

The total length of fissure 4 was about $3.9 \mathrm{~km}$ and the largest escarpment can be up to $30 \mathrm{~cm}$ (figure 3c). This fissure occurred in 1995 and affected three villages. Its distance from the ZM was $9.5 \mathrm{~km}$. During the filed survey, it was observed that the vertical offset at the center of fissure was larger than that in the edges, suggesting that this fissure has propagated from the center. Its extension direction was NE35 ${ }^{\circ}-\mathrm{NE} 55^{\circ}$.

Fissure 5 was located in the western margin of Qinglong Graben and occurred in August 6, 1978 in Taocun (Wang 1984). Since then, it has always extended towards north. With a length of $10.5 \mathrm{~km}$, it was the longest fissure in Qinglong Graben until August 10, 2013. The trend of this fissure was in the range of $\mathrm{NE} 35^{\circ}-\mathrm{NE} 45^{\circ}$. The scarp was $40 \mathrm{~cm}$ and the width increased by erosion processes after anomalous heavy rainfall and irrigations (figure 3d). The distance of this fissure from the $\mathrm{ZM}$ is $12.6 \mathrm{~km}$.

All of the five earth fissures showed vertical offsets and horizontal displacements; however, the horizontal displacements were much lesser than the vertical offsets. During the field surveys, these earth fissures were found to be commonly eroded into sinks and gullies by overland flow after irrigation and anomalous heavy rainfalls (figure $3 \mathrm{~d}$ ).

\section{Methodology}

The geological study was conducted through site investigation, geological drilling and trench excavation method. The site investigation was carried out to study the characteristics of the earth fissures in Qinglong Graben. The width, depth and position of earth fissures were respectively measured by calibrated steel tapes and hand-held GPS. Especially, the occurrence time of earth fissures was acquired by visiting the local resident. Especially, by the time of field visits during July 2, 2013 to August 25,2013 , authors found the width of earth fissure in one site of fissure 2 and two sites of fissure 5 increased after anomalous heavy rainfall, and one site of fissure 1, one site of fissure 3 and two sites of fissure 4 increased after irrigation. It had gone from thin linear fissure to gully line or sinkholes.

This paper arranged five geological drilling lines that were perpendicular to each earth fissure. Five geological drilling lines were measured by level. Every line consisting of five or six drills was arranged on both sides of the earth fissure oriented at NW315 ${ }^{\circ}$ There were two drills on the uplifted side and others on downthrown side. The diameter of drills was $108 \mathrm{~mm}$ and the depth of drills ranged from 50 to $70 \mathrm{~m}$. In addition, four trenches with $8 \mathrm{~m}$ width, $26 \mathrm{~m}$ length and $8 \mathrm{~m}$ depth were excavated to study the relation between the earth fissures and buried faults. The geometry of trench has stepped 


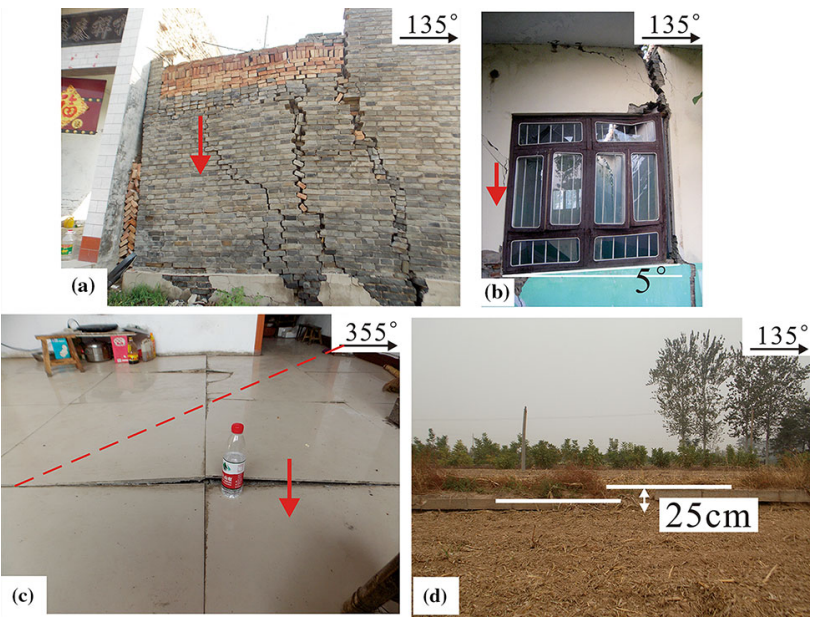

Figure 4. Damages caused by earth fissures.

appearance and the long axis direction of trench was perpendicular to earth fissure. Four trenches were arranged on fissure 1, fissure 2, fissure 4 and fissure 5 (figure 2).

\section{Results}

\subsection{General damage related to surface deformation}

During our field surveys, we found that the earth fissures had resulted in topographic changes that affected buildings and roads. While the earth fissures ran across the buildings, uneven differential subsidence destroyed buildings, including cracks in walls (figure 4a), doors and windows deformation (figure 4b), and arch on the floor (figure 4c).

The earth fissures have also damaged irrigation systems, such as water channels were dislocated and the separation was up to $25 \mathrm{~cm}$ (figure $4 \mathrm{~d}$ ). They can act as pathways for rapid infiltration during heavy rainfall and irrigation events. This erosion processes can cause piping that increased the width of earth fissures (figure 3d). After a sinkhole or gully occurred in farmland, it destroyed the integrity of farmland causing agricultural damage.

\subsection{Geological cross-section revealed by drilling}

The geological cross-section of earth fissure at the depth of 0 to $-60 \mathrm{~m}$ was revealed by drilling. As shown in figures 5 and 6 , the two drilling profile lines, D1 and D4 in figure 2, are located at the middle section of fissure 1 and fissure 4, respectively, basically representing the overall situation of the

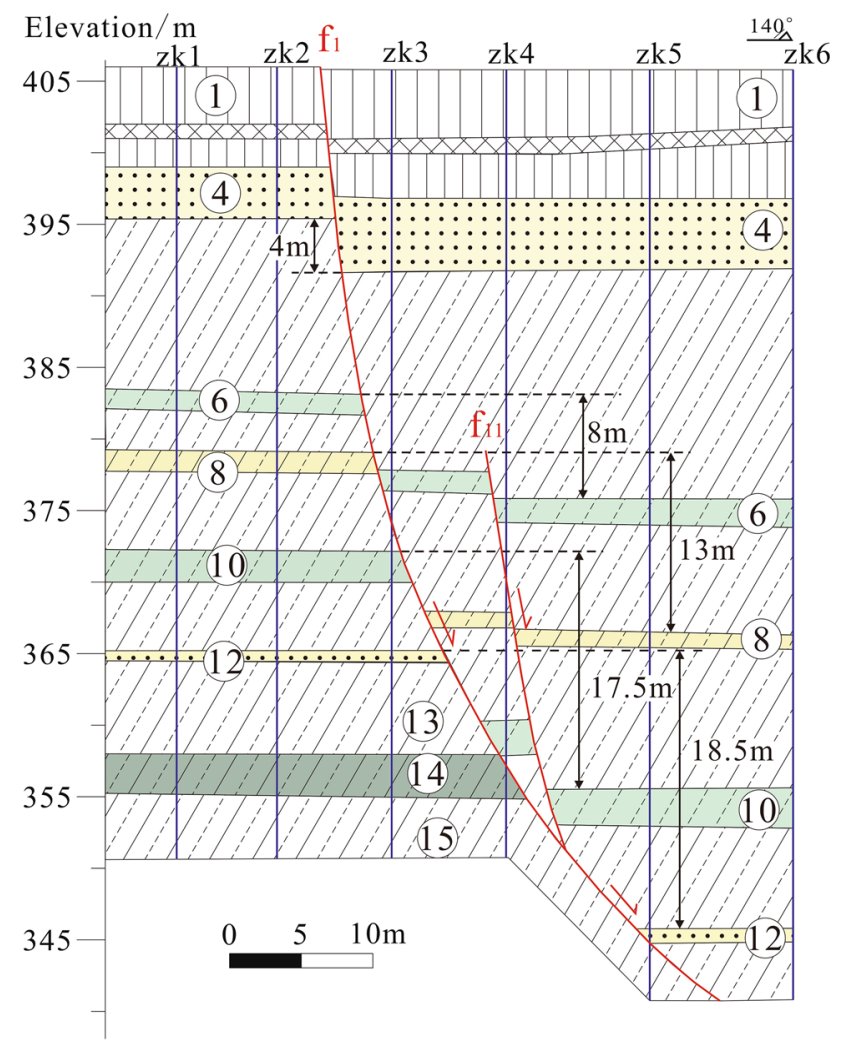

Figure 5. Geological cross-section of earth fissure 1. (1) Loess with wormhole and shell fragments, tawny, dampish; (2) Loessial soil (Heilu soil) with wormhole and calcium film, taupe gray, dampish; (3) Loess with wormhole and shell fragments, tawny, dampish; (4) Medium sand containing mica, feldspar and quartz, yellowish, dampish, medium dense; (5) Silty clay with mica, ferro-manganese concretion and silty sand, yellowish, tawny, wet; (6) Silty clay with mica, ferromanganese and shell fragments, celadon, saturation; 7 Silty clay containing mica and ferro-manganese concretion, tawny, saturation; (8) Silty clay with mica, silt and ferro-manganese, grayish yellow, saturation; (9) Silty clay containing mica, ferric oxide lump and shell fragments, tawny, saturation; (10) Silty clay with mica, ferric oxide lump and shell fragments, celadon, saturation; (11) Silty clay with mica, ferric oxide lump and shell fragments, tawny, saturation; (12) Medium sand with mica, feldspar and quartz, yellowish, saturation, dense; (13) Silty clay with mica, ferric oxide lump and shell fragments, tawny, saturation; (14) Silty clay with mica, ferric oxide lump and shell fragments, celadon, saturation; (15) Silty clay with mica, ferric oxide lump and shell fragments, tawny, saturation.

regional strata. The geological cross-section of fissure 1 shows that all strata on both sides of earth fissure were dislocated by fissure 1 and the dip separation on the fourth stratum was $4 \mathrm{~m}$, on the sixth stratum was $8 \mathrm{~m}$, on the eighth stratum was $13 \mathrm{~m}$, on the tenth stratum was $17.5 \mathrm{~m}$, and on the twelfth stratum was $18.5 \mathrm{~m}$ (figure 5). The geological cross-section of fissure 4 shows that all 


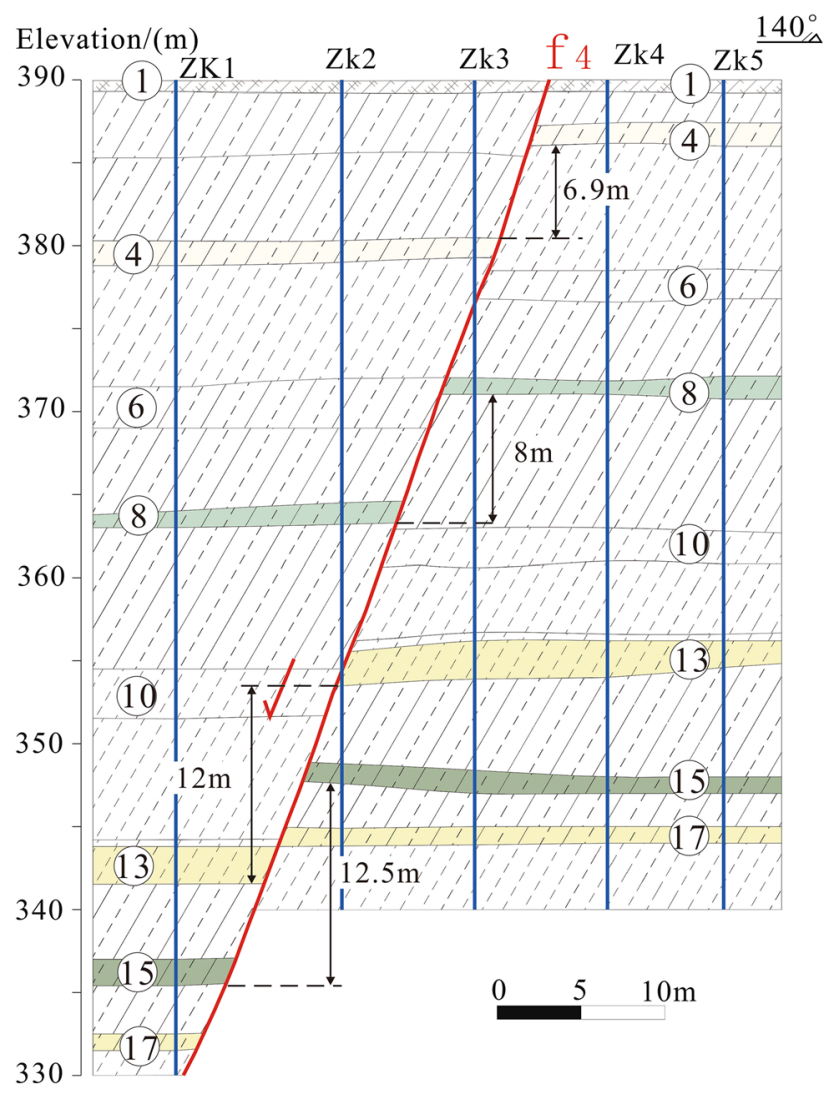

Figure 6. Geological cross-section of earth fissure 4. (1) Miscellaneous fill; (2) Loess with wormhole and shell fragments, tawny, dampish; (3) Silty clay with mica, ferromanganese concretion and shell fragments, yellowish, tawny, saturation; (4) Silty clay containing mica, ferro-manganese concretion and shell fragments, celadon, saturation; (5) Silt containing mica and silty-fine sand, tawny, yellowish gray, saturation, medium dense; (6) Silty clay with mica, ferromanganese concretion and shell fragments, tawny, saturation; (7) Silty clay containing mica, ferro-manganese concretion and shell fragments, grayish yellow, gray, saturation; (8) Silty clay containing mica, ferro-manganese concretion and shell fragments, celadon, saturation; (9) Silty clay with mica, silt and shell fragments, tawny, saturation; (10) Silt containing mica and silty-fine sand, grayish yellow, saturation, medium dense; (11) Silt containing mica and silty clay, tawny, grayish yellow, saturation, medium dense; (12) Silty clay containing mica, ferro-manganese concretion and shell fragments, celadon, saturation; (13) Silty clay containing mica, ferro-manganese concretion and shell fragments, yellowish gray, gray, saturation; (14) Silty clay containing mica, ferromanganese concretion and shell fragments, tawny, hoary, saturation; (15) Silty clay containing mica, ferro-manganese concretion and shell fragments, celadon, saturation; (16) Silty clay containing mica, ferro-manganese concretion and shell fragments, yellowish gray, gray, saturation; (17) Silty clay containing mica, ferro-manganese concretion and shell fragments, celadon, saturation; (18) Silt containing mica and silty-fine sand, grayish yellow, saturation, medium dense.

strata on both sides of earth fissure were dislocated by fissure 4 and the dip separation on the fourth stratum was $6.9 \mathrm{~m}$, on the eighth stratum was $8 \mathrm{~m}$, on the thirteenth stratum was $12 \mathrm{~m}$, and on the fifth stratum was $12.5 \mathrm{~m}$ (figure 6 ). These results indicate that all strata are dislocated by earth fissures and the dislocation increased with increasing depth. The displacement of fissure 4 at the depth of $0-30 \mathrm{~m}$ is larger than fissure 1 , and the displacement of fissure 4 at the depth of -30 to $-60 \mathrm{~m}$ is smaller than fissure 1 . However, the displacement at earth surface is approximately equal.

\subsection{Geological cross-section revealed by trench}

The excavation trench was conducted at four earth fissures except fissure 3, and the shallow crosssection is shown in figure 7 . The result revealed that the earth fissures had the following characteristics. (1) Secondary fracture existed in shallow strata and in combination with the earth fissure formed the fracture zone. The width of fracture zone on fissure 1 was $12.2 \mathrm{~m}$, on fissure 2 was $10.1 \mathrm{~m}$, on fissure 4 was $>8.3 \mathrm{~m}$, and on fissure 5 was $>11 \mathrm{~m}$. (2) With steep dip angle in the shallow-surface, fissure 4 and fissure 5 were nearly vertical, the dip angle of fissure 1 and fissure 2 was $80^{\circ}$. (3) Shallow layers were all dislocated by the earth fissures. However, the vertical displacement increased with increase in the depth. For example, the photograph of fissure 1 trench revealed that the vertical displacement on the second strata was $25 \mathrm{~cm}$, and on the fifth strata was $200 \mathrm{~cm}$ (figure 8). The photograph of fissure 2 trench showed that the vertical offset on the second strata was $200 \mathrm{~cm}$, and on the fifth strata was $400 \mathrm{~cm}$ (figure 9). (4) The width of earth fissure was the largest on surface and decreased with increasing depth. For example, figure 9 showed that the width of earth fissure was $80 \mathrm{~cm}$, and at the bottom of trench was only $1 \mathrm{~cm}$.

\section{Discussion}

Three issues need to be examined in ascertaining the cause of earth fissures in Qinglong Graben: (1) explain why the fissures are aligned stably between $35^{\circ}$ and $65^{\circ} \mathrm{NE}$, nearly parallel with each other and the trend of Qinglong Graben; (2) the cause of the vertical dislocation of $30 \mathrm{~cm}$ at the surface of the modern earth fissure; and (3) the role of erosion. These problems are analyzed in three aspects as follows. 
(a)

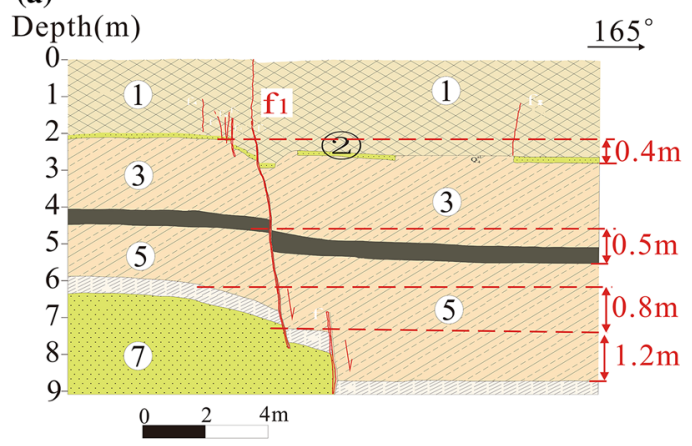

(c)

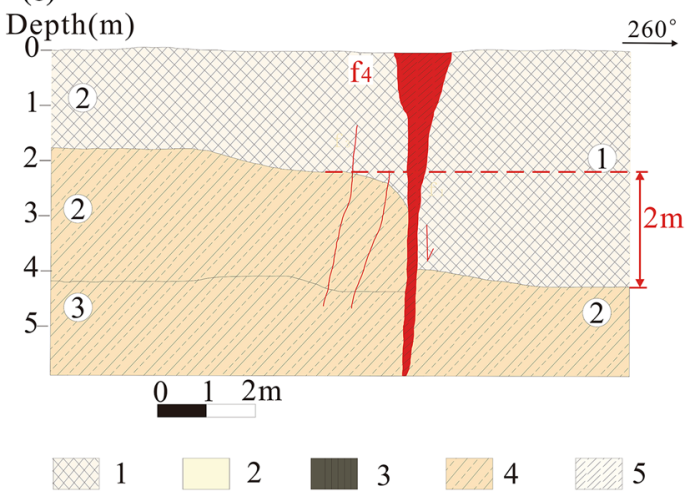

(b)

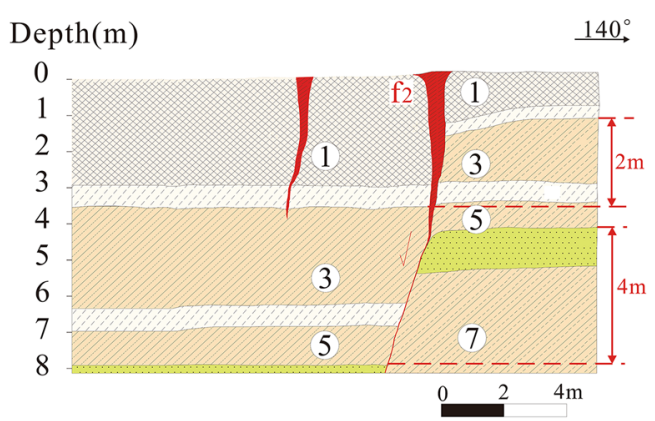

(d)

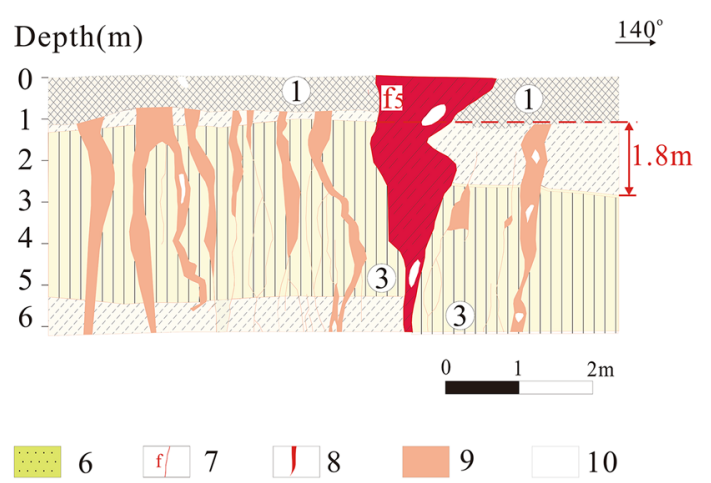

Figure 7. Cross-sections of the open trench excavation of Qinglong Graben. 1: Qpd, 2: Loess, 3: Heilu soil, 4: Silty clay, 5: Silt, 6: Medium sand, 7: Earth fissure, 8: Old earth fissure, 9: Filler, 10: Cave.

\subsection{Fissure controlled by buried fault}

Yuncheng Basin is located in southern Fenwei Basin. Under the effect of Himalaya and Tibet collision, sinistral of Ordos block, and eastern tensile of the North China block, Fenwei Basin had NW-SE extension (Deng et al. 1999) (figure 11a), which provided tensile stress field for the buried faults. In addition, Deng et al. (2013) generalized the deep tectonic mold of Wei River Basin as upper mantle uplifting, middle crust lateral stretching and upper crust tension. These authors mentioned that the tensile stress environment was formed by upper mantle uplifting, and middle crust lateral stretching and it was the main power source for the development of the earth fissures. Both Yuncheng Basin and Wei River Basin belong to Fenwei Basin, and they have similar deep tectonic mold with upper mantle uplifting. Liu et al. (1996) agreed that the regional tectonic tension stress field of Yuncheng Basin was NW-NWW direction. The filed investigation results showed that the strike of earth fissures in Qinglong Graben ranged from $\mathrm{NE} 35^{\circ}$ to $\mathrm{NE} 65^{\circ}$, which is nearly perpendicular to the direction of tectonic tension stress.
Filed investigation results showed that all the five earth fissures have vertical offsets. The vertical offsets and the distance of the earth fissures from the ZM are shown in figure 10. The vertical offset of the earth fissure at the center of Qinglong Graben was much less than the others. On the basis of the five earth fissures' drilling result, a combined geological cross-section was drawn, as shown in figure 10 . The results showed many buried active faults in the study area. Quaternary strata were dislocated to different extents by these buried active faults. The fault displacement increased with an increase in depth. Therefore, these buried active faults belong to syn-sedimentary faults. In addition, trench results revealed that the five earth fissures in Qinglong Graben are all connected with buried active faults and expanded from deep underground. They share the same characteristics with syn-sedimentary faults, such as the emerging lines or outcropping of syn-sedimentary faults at the ground surface. Hence, the syn-sedimentary fault is key factor of the earth fissures in Qinglong Graben.

Therefore, the regional tectonic tension stress field was formed by upper mantle uplifting, middle crust lateral stretching and upper crust tension. 


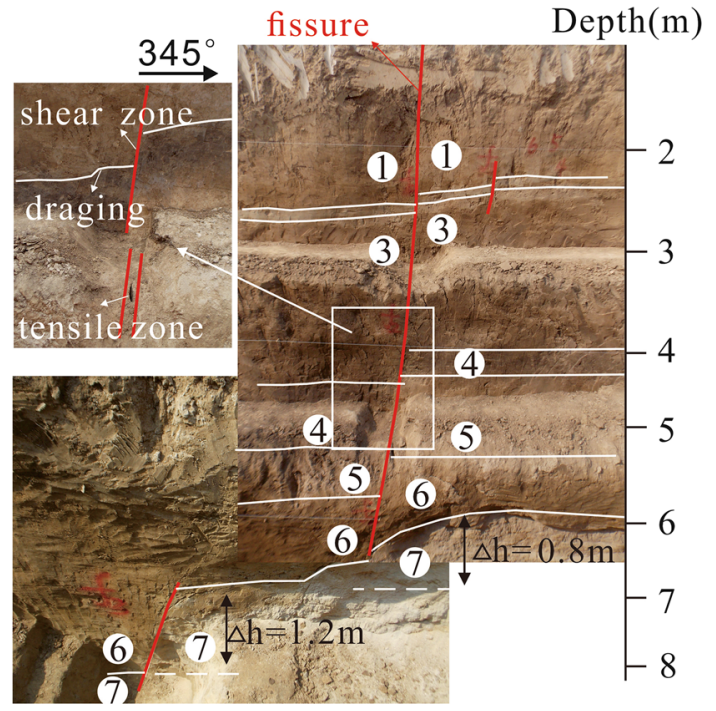

Figure 8. Photograph of fissure 1 trench. (1) Qpd, (2) Medium sand, (3) Silty clay, (4) Heilu soil, (5) Silty clay, (6) Silt, (7) Medium sand.

Many buried faults were formed under the action of tensile stress, and they were the 'prototype' of earth fissures (figure 11b).

\subsection{Fissure shaped by groundwater overexploitation}

The active rate of $\mathrm{F} 1$ was in the range 0.22 $0.55 \mathrm{~mm} / \mathrm{a}$ (Miao et al. 2014), and the active rate of F4 was $<0.1 \mathrm{~mm} / \mathrm{a}$ (Li et al. 1994). However, field results showed that the active rates of earth fissures

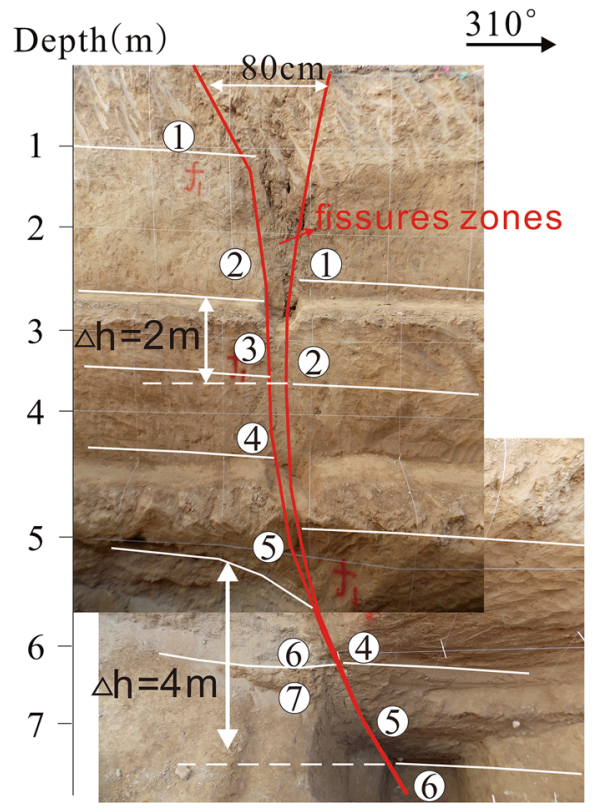

Figure 9. Photograph of fissure 1 trench. (1): Qpd, (2) Silt, (3) Silty clay, (4) Silt, (5) Silty clay, (6) Medium sand, (7) Silty clay.

(figure 12) in Qinglong Graben were all far more than the active rate of $\mathrm{F} 1$ and $\mathrm{F} 4$. For example, the active rate of fissure 1 was $1.92 \mathrm{~cm} / \mathrm{a}$, fissure 2 was $1.67 \mathrm{~cm} / \mathrm{a}$, fissure 3 was $0.22 / \mathrm{a}$, fissure 4 was $1.67 \mathrm{~cm} / \mathrm{a}$ and fissure 5 was $1.14 \mathrm{~cm} / \mathrm{a}$. Hence, synsedimentary fault is not the only factor of earth fissure in Yuncheng Basin.

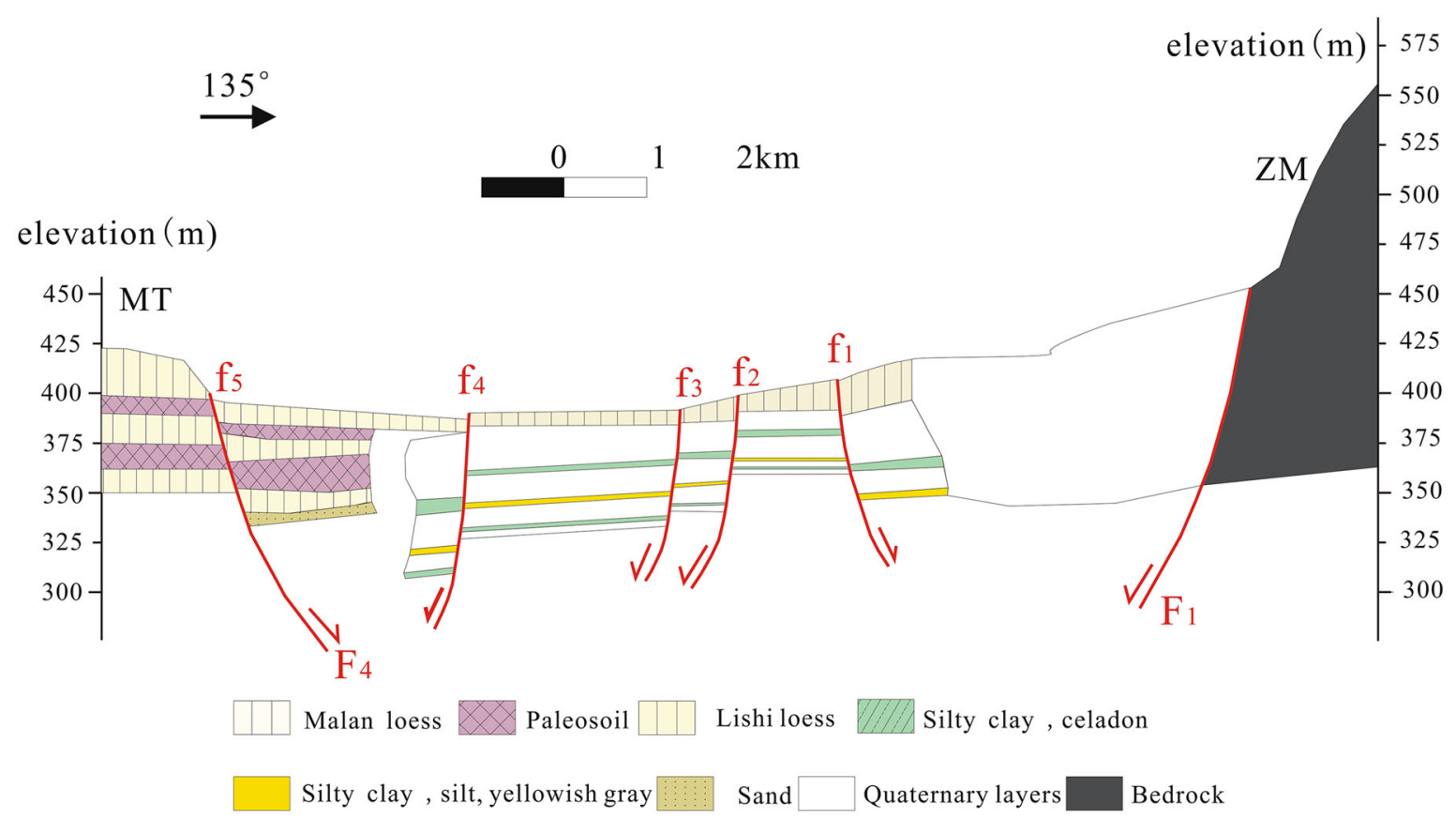

Figure 10. Geological cross-section of the earth fissures in Qinglong Graben. 

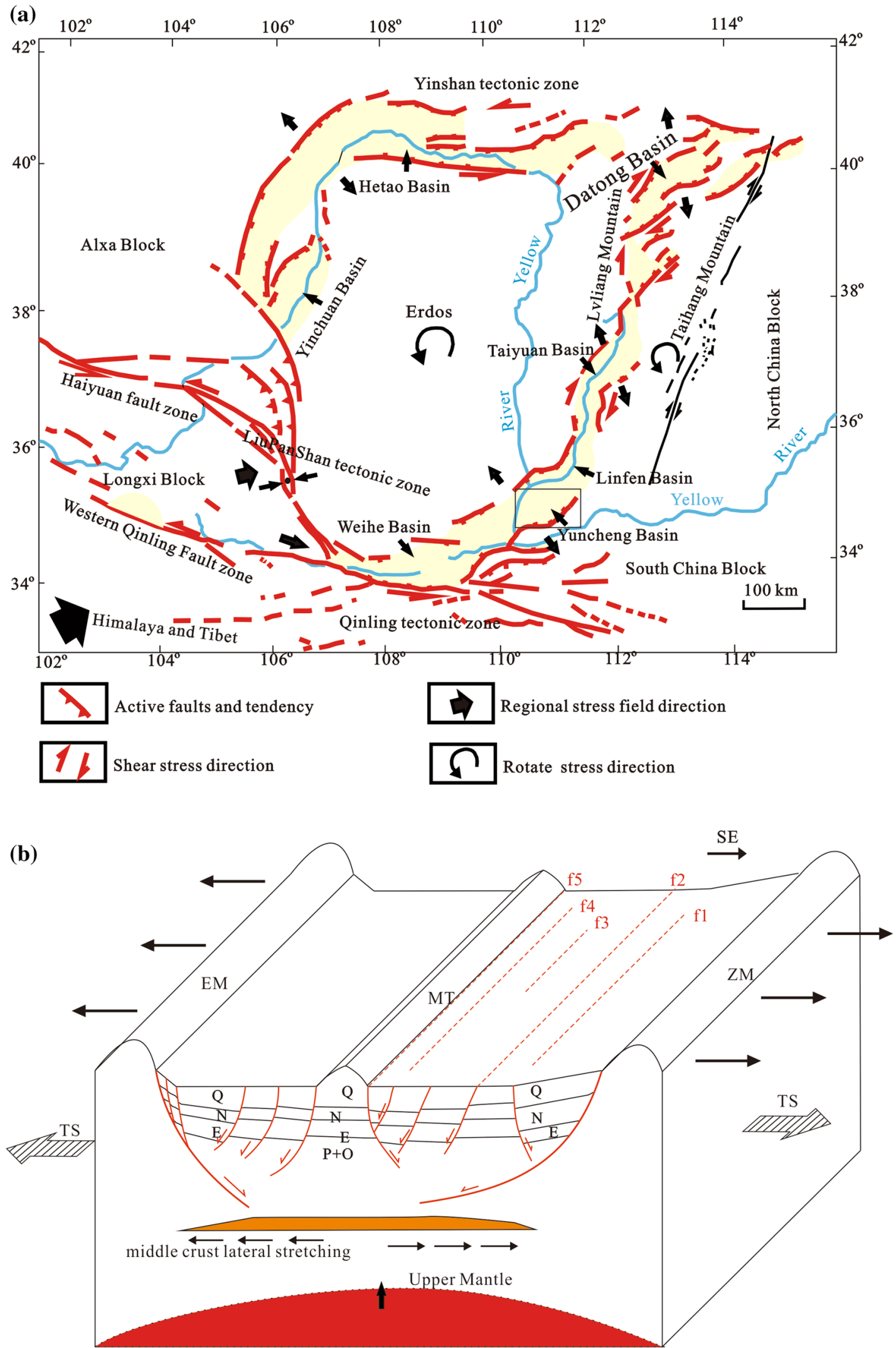

TS: Tensile stress $\quad$ ZM: Zhongtiao Mountain $\quad$ MT: Mingtiaogang EM: Eemei Mesa

Figure 11. The relationship between deep tectonic mold and the earth fissures. 


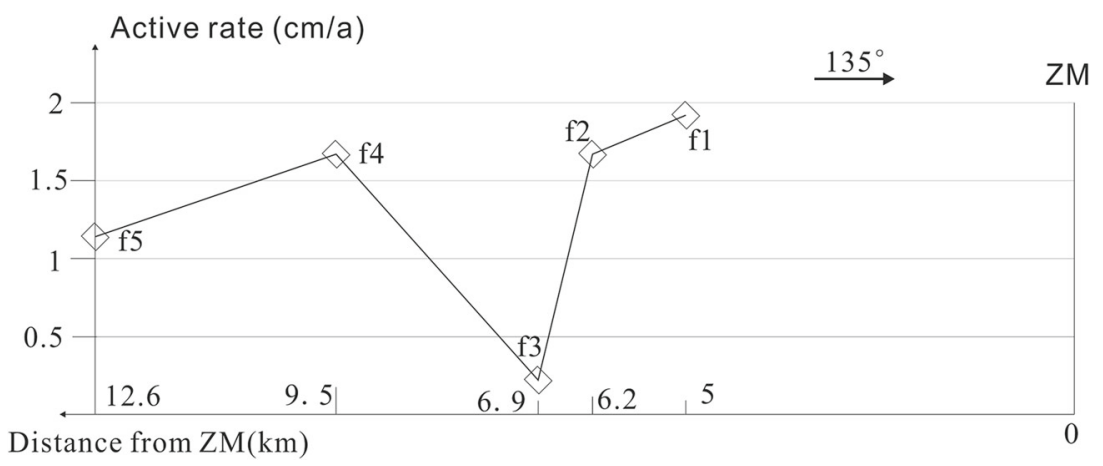

Figure 12. Active rate of earth fissures and the distance from ZM.

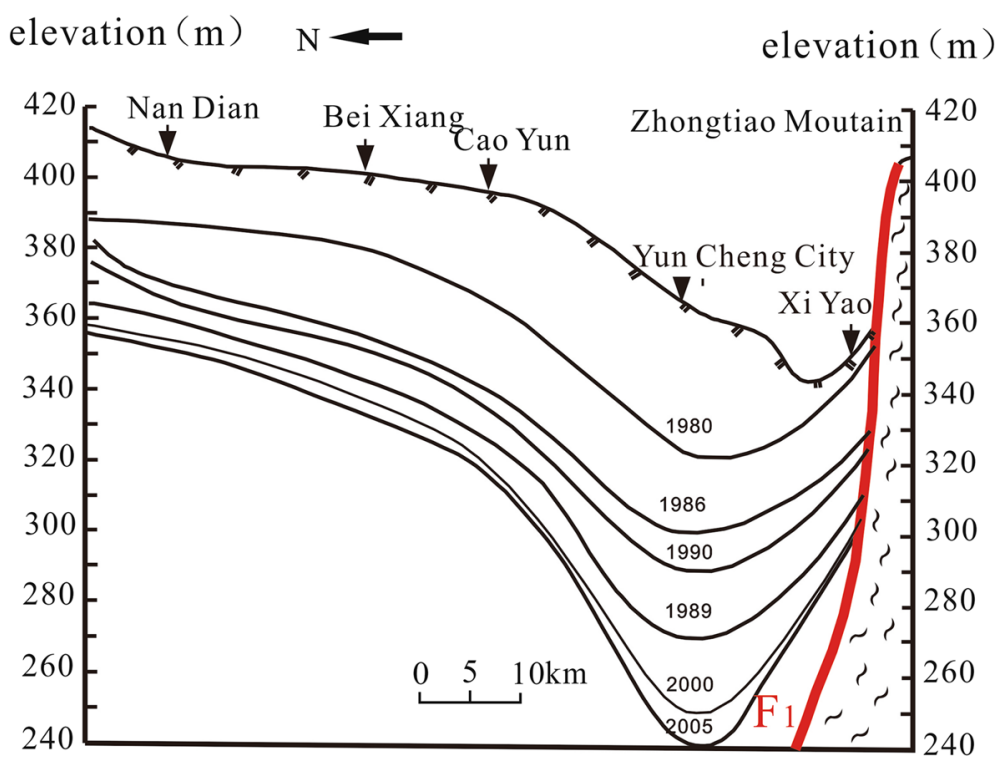

Figure 13. Changes in groundwater level from 1980 to 2005 (China Geological Survey 2008).

Overexploitation of medium and deep aquifer groundwater began in 1970s, and since then, the groundwater level has been declining with the cone of depression in Yuncheng city (China Geological Survey 2008) (figure 13). With increased pumping of the groundwater, the cone of depression increased. As shown in figure 13, the groundwater declined only $40 \mathrm{~m}$ in 1980 , whereas, in 2005 , it declined $120 \mathrm{~m}$. The average decline rate can be up to $3.43 \mathrm{~m} / \mathrm{a}$. The drilling result showed that the strata in the near-surface consists mostly lacustrine deposits. Wang et al. (2000) reported that the Quaternary strata in Qingloing Graben are mostly lacustrine deposits. According to Burbey (2002), long-term pumping of groundwater and a considerable thickness of compressible layers are important causes for the occurrence of earth fissures. Therefore, we propose that overexploitation of groundwater and pre-excited layer conditions are other important factors for the occurrence of earth fissures in Qinglong Graben.

\subsection{Fissure developed by erosion}

During field investigation, we found that the width of the earth fissures increased after anomalous heavy rainfall and irrigation. The earth fissures then show gully lines or sinkholes on the surface (figures $3 \mathrm{~d}$ and $4 \mathrm{f}$ ). In addition, drilling results showed that the strata on the surface were loess which is easily eroded. Hence, erosion process resulting from overland flow is also an important factor for the development of earth fissures.

In conclusion, earth fissures found in Qinglong Graben can be divided into three stages. Firstly, in the tensile stress environment, five secondary faults occurred on the hanging wall of F1 and F4. These secondary faults were syn-sedimentary faults. Although they dislocated the Quaternary layers, they did not extend to the surface (figure 14a). These syn-sedimentary faults are 'prototype' of five earth fissures. Secondly, the different 

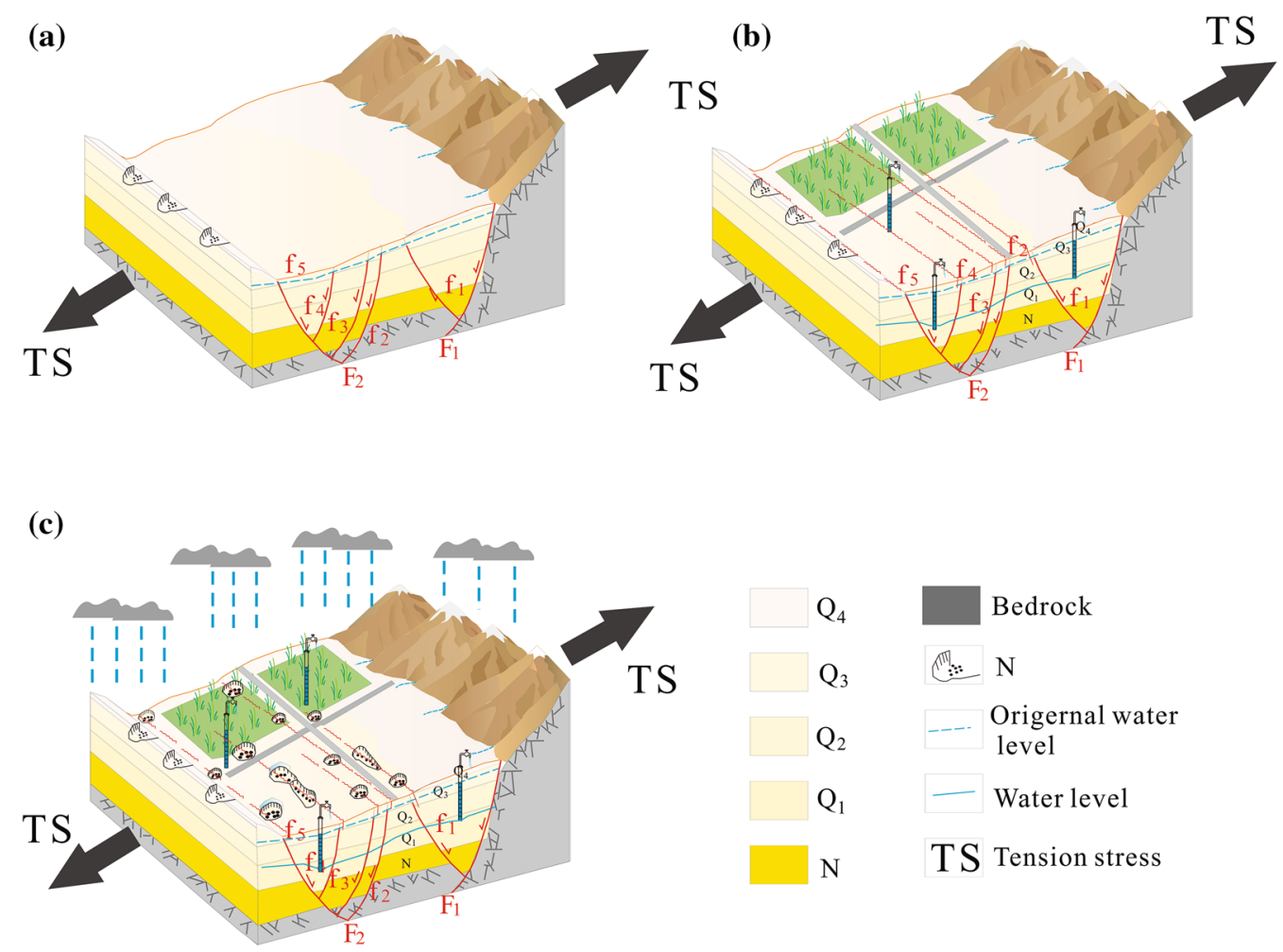

Figure 14. Processes of earth fissures in Qinglong Graben.

land subsidence, resulting from over-exploitation of groundwater, increased the rate of syn-sedimentary faults extension and caused the syn-sedimentary faults to extend to the surface and form earth fissures (figure 14b). Third, the erosion process resulting from overland flow made the earth fissures to emerge as gullies and sinkholes (figure 14c).

\section{Conclusions and recommendation}

In order to ascertain the distribution and cause of earth fissures formation, this research employed a series geological investigation consisting of field investigation, geological drilling and trench excavation. Field investigation identified that five earth fissures in Qinglong Graben are in line semi-parallel to each other and to flaked normal faults. They are almost similar in trend of Qinglong Graben. Geological drilling and trench excavation indicated that the earth fissures in Qinglong Graben are connected with pre-excited active faults, which are the key factors for the origin of those earth fissures. Furthermore, erosion process resulting from overland flow is an important factor of earth fissures development.
Moreover, the regional tectonic tension stress field formed by upper mantle uplifting also offers a favourable environment for the origin of earth fissures. Overexploitation of groundwater has important contribution to make the rate of earth fissures much larger than the rate of F1. Hence, earth fissure formation in Qinglong Graben can be divided into three stages.

In view of the above conclusions, this paper suggest that government strengthen the protection of groundwater and limit the exploitation of groundwater in Qinglong Graben to prevent future loss of property and lives.

\section{Acknowledgements}

The authors wound like to thank China Geological Survey for supporting this work and acknowledge the great help and support from all who participated in the works carried out for this study.

\section{References}

Allis R G 2000 Review of subsidence at Wairakei field, New Zealand; Geothermics 29(4-5) 455-478. 
Ayalew L, Yamagishi H and Reik G 2004 Ground cracks in Ethiopian Rift Valley: Facts and uncertainties; Eng. Geol. 75 309-324.

Bell J W 1981 Subsidence in Las Vegas Valley; Nev. Bur Mines Geol. Bull. 95 84p.

Budhu M 2008 Mechanics of earth fissures using the MohrCoulomb failure criterion; Environ. Eng. Geosci. 14(4) $281-295$.

Budhu M 2011 Earth fissure formation from the mechanics of groundwater pumping; Int. J. Geomech. 11(1) $1-11$.

Burbey T J 2002 The influence of faults in basin-fill deposits on land subsidence, Las Vegas Valley, Nevada, USA; Hydrogeol. J. 10 525-538.

Carpenter M C 1993 Earth fissure movements associated with fluctuations in groundwater levels near the Picacho Mountains, south-central Arizona, 1980-1984; US Geol. Surv. Prof. Pap. 497-H 49p.

Cheng S P and Yang G Z 2002 Late quaternary segmentation model of the Zhongtiaoshan fault, Shanxi province; Seismol. Geol. 3 289-302 (in Chinese).

China Geological Survey 2008 Survey and evaluate on groundwater resources and environmental problem in Shanxi Graben Systems; Geology Publishing House, 142p (in Chinese).

Deng Q D, Cheng S P, Min W, Yang G Z and Ren D W 1999 Discussion on Cenozoic tectonics and dynamics of Ordos block; J. Geomech. 5(3) 13-21 (in Chinese).

Deng Y H, Peng J B, Mu H D, Li L and Sun Z F 2013 Inoculation mechanism of deep tectonic activities of ground fissures in the WRB; J. Jilin Univ. (Earth Sci. edn) 2 521-527 (in Chinese).

Feth J H 1951 Structural reconnaissance of the Red Rock quadrangle, Arizona; US Geol Surv Open-File Report, Tucson AZ, 32p.

Helm D C 1994 Hydraulic forces that play a role in generating fissures at depth; Bull. Assoc. Eng. Geol. 31 293-304.

Holzer T L and Galloway D L 2005 Impacts of land subsidence caused by withdrawal of underground fluids in the United States; Rev. Eng. Geol. 16(8) 87-99.

Jachens R C and Holzer T L 1979 Geophysical investigations of ground failure related to ground-water withdrawal Picacho Basin, Arizona; Ground Water 17 574-585.

Jachens R C and Holzer T L 1982 Differential compaction mechanism for earth fissures near Casa Grande, Arizona; Geol. Soc. Am. Bull. 93 998-1012.

Lee C F, Zhang J M and Zhang Y X 1996 Evolution and origin of the ground fissures in Xian, China; Eng. Geol. 43(1) 45-55.

Li Y L, Yang J C and Su Z Z 1994 Neotectonic movement and palaeochannel evolution in Yuncheng Basin; Shanxi Earthq. Res. 1 3-6 (in Chinese).

Li Y, Yang J and Hu X 2000 Origin of ground fissures in the Shanxi Graben System, northern China; Eng. Geol. $55267-275$.

Liu W, An W P and Zhao X P 1996 Recent tectonic movement and recent crust stress field in Yuncheng Basin; Shanxi Earthq. Res. 2 9-13 (in Chinese).

Liu H J, Liu C, Huang Q B and Lu Q Z 2013 Characteristics and evaluation of ground fissures along Datong-Xi'an passenger dedicated line in Yuncheng Basin; Railw. Constr. Technol. 1 114-119 (in Chinese).
Lofgren B E 1978 Hydraulic stresses cause ground movement and fissures, Picacho Arizona; Geol. Soc. Am. Abstr. Programs 10271 .

Martin H and Burbey T 2010 Controls on initiation and propagation of pumping-induced earth fissures: Insights from numerical simulations; Hydrogeol. J. 18(8) 17731785 .

Miao D Y, Li Y L, Lv S H, Tian J M, Wang Y R and Si S P 2014 Neotectonic activity in Xiaxian segment of the north ZM fault zone; Shanxi Geogr. Res. 4 665-673 (in Chinese).

Ngecu W M and Nyambok I O 2000 Ground subsidence and its socio-economic implications on the population: A case study of the Nakuru area in Central Rift Valley, Kenya; Environ. Geol. 39(6) 567-574.

Pacheco-Martínez J, Hernandez-Marín M and Burbey $\mathrm{T}$ J et al. 2013 Land subsidence and ground failure associated to groundwater exploitation in the Aguascalientes Valley, Mexico; Eng. Geol. 164(18) 172 186.

Peng J B, Chen L W, Huang Q B, Men Y M, Fan W, Yan K, Li K, Ji Y S and Shi Y L 2008 Large-scale physical simulative experiment on ground fissure expansion mechanism; Chin. J. Geophys. 51(6) 1826-1834 (in Chinese).

Peng J B, Chen L W, Huang Q B, Men Y M, Fan W and Yan J K 2013 Physical simulation of ground fissures triggered by underground fault activity; Eng. Geol. 15519 30.

Ramelli A R, dePolo C M and Yount J C 2003 Ground cracks associated with the 1994 double spring flat earthquake, west-central Nevada; Seismol. Soc. Am. Bull. 93(6) 27622768.

Rudolph D L, Cherry J A and Farvolden R N 1991 Groundwater flow and solute transport in fractured lacustrine clay near Mexico city; Water Resour. Res. 27(9) 21872201.

Sapigni M, Barbera G L and Ghirotti M 2003 Engineering geological characterization and comparison of predicted and measured deformations of a cavern in the Italian Alps; Eng. Geol. 69 47-62.

Sarkar I 2004 The role of the 1999 Chamoli earthquake in the formation of ground cracks; J. Asian Earth Sci. 22 529-538.

Sheng Z P, Helm D C and Li J 2003 Mechanisms of earth fissuring caused by groundwater withdraw; Environ. Eng. Geosci. 9(4) 351-352.

Sun P, Peng J B, Chen L W, Yin Y P and Wu S R 2009 Weak tensile characteristics of loess in China - An important reason for ground fissures; Eng. Geol. 108 153-159.

Tian J M, Li Y L, Si S P, Lv S H and Wang Y R 2013 Discovery and neotectonic significance of fault scarps on alluvial fans in the middle of northern Piedmont of the Zhongtiao Mountains; Acta Sci. Nat. Univ. Pekin. 6 986992 (in Chinese).

Wang S Z 1984 Earth fissure in Yuncheng; Shanxi Earthq. Res. 3 17-19 (in Chinese).

Wang Q, Li C G, Tian G Q, Zhang W Z, Liu C, Ning L Y, Cheng Z G, He C Y and Yue J 2000 The tectonic setting of earth surface system mega-evolution and Salt Lake formation since 7.1 Ma in Yuncheng Basin; Chin. Sci. Ser. D 4 420-428. 
Wang J M, Wang C M and Liu K 2001 Progress in ground fissures and its hazard research; Adv. Earth Sci. 3 304-313 (in Chinese).

Wang Y R, Li Y L, Yan D D, Lv S H and Si S P 2015 Holocene paleoseismology of the middle and south segments of the north Zhongtiaoshan fault zone, Shanxi; Seismol. Geol. 37 1-12 (in Chinese).

Williams F M, Williams M A J and Aumento F 2004 Tensional fissures and crustal extension rates in the northern part of the Main Ethiopian Rift; J. Afr. Earth Sci. 38 183-197.

Wu Q, Ye S, Wu X and Chen P 2004 Risk assessment of earth fractures by constructing an intrinsicvulnerability map, a specific vulnerability map, and a hazard map, using Yuci city, Shanxi, China as an example; Environ. Geol. 46(1) 104-112.

Xu J S, Zhuang H D, Tang D Q and Li Z C 2010 Characteristic and mechanism analysis of ground fissure in Yuncheng Basin; J. Geol. Hazards Environ. Preserv. 2 97-100 (in Chinese).

Youssef A M, Sabtan A A and Maerz N H et al. 2014 Earth fissures in Wadi Najran, Kingdom of Saudi Arabia; Nat. Hazards 71(3) 2013-2027.

Zhang S M 2000 Basin evolutionary differences and seismotectonics of Fen Wei Graben system; J. Geomech. 2 30-37 (in Chinese).

Corresponding editor: SAIBAL GuPtA 